Saheed, D.O., Ajibola, I.M., \& Adedoyin, L. (2021). Efficacy of Audit Fee on Audit Quality of Selected Pharmaceutical Firms in Nigeria. Copernican Journal of Finance \& Accounting, 10(1), 53-66. http://dx.doi.org/10.12775/CJFA.2021.003

\author{
Daud Omotosho Saheed* \\ Kwara State University \\ Ibrahim Majeed Ajibola** \\ Kwara State University \\ LUKMAN Adedoyin ${ }^{* * *}$ \\ Federal Polytechnic Offa
}

\title{
EFFICACY OF AUDIT FEE ON AUDIT QUALITY OF SELECTED PHARMACEUTICAL FIRMS IN NIGERIA
}

Keywords: audit fee, audit quality, audit report lag, mandatory auditor rotation.

J E L Classification: M42, 014, L29, C14, C23.

Abstract: The problem of poor accuracy and credibility in some audited financial statement has being a major form of information asymmetry which had led some shareholders and prospective investors to make wrong Judgment about the financial position of some organization due to poor audit quality. Thus, Specifically this study empirical-

Date of submission: November 15, 2020; date of acceptance: January 26, 2021.

* Contact information: oshoprints@gmail.com, Department of Accounting and Finance, Kwara State University, Malete, Nigeria; phone: +2347036215657; ORCID ID: https://orcid.org/0000-0003-1365-2860.

** Contact information: ajibolamagaji@gmail.com, Department of Accounting and Finance, Kwara State University, Malete, Nigeria; phone: +2347032873780; ORCID ID: https://orcid.org/0000-0003-2293-3453.

*** Contact information: orimustrock@yahoo.com, Department of Accountancy, The Federal Polytechnic Offa, Nigeria; phone: +2348032440434; ORCID ID: https://orcid. org/0000-0001-5459-3364. 
ly examine how audit fee, audit report lag as well as mandatory auditor rotation affect the audit quality of the sample listed pharmaceutical firms on the floor of the Nigerian Stock Exchange. A GLS estimation method was employed to clearly establish the nature relationship that exists between the dependent variable and the adopted surrogates for the independent variables. A Secondary data was extracted from the annual audited reports from the ten selected pharmaceutical firms that serve as the fair representation for the population under study for a period of ten years 2009-2019. The result from the finding shows that all the adopted surrogates for the independent variable were jointly significant in explaining about $72 \%$ variation in audit quality given credence to the coefficient of (R2) which stood at 0.72 as well as the combined p-value of 0.000 . This implies that the predictive power of the surrogates of the independent variables can explain about $72 \%$ changes in audit quality of the population under study. In specific terms; Audit fee have a significant positive impact on audit quality of the selected pharmaceutical firms while audit report lag and mandatory auditor rotation have significant negative impact the audit quality of the selected pharmaceutical firms respectively. The study therefore recommends among many others that policy makers and regulators should put in place a framework that will ensure the payment of optimal compensation to audit firm as audit fee as this will no doubt go a long way in improving the audit quality of the firms under study.

\section{IIIINTRODUCTION}

Audit quality has been a major focus research area in advanced countries for several decades given credence to the role of auditors' reports in intending investors decisions making. Considering several accounting scandals and the financial crisis, which were in connection with financial statement misrepresentations. Akin (2017) opined that disclosure is one of the accounting principles for which, all information relating to the Company's activities appropriate and timely manner, can be made available to different groups of users for the purpose of investments decision, interpretation of corporate financial status, evaluating management performance and prediction of future cash flows. In this regard all the important facts of the economic are properly and are fully disclosed, to provide a decision and possibly to avoid confusion. As a result, the quality of information disclosed is very important because the quality audit conducted usually have an influence on the credibility of the disclosure made by a company (Shen \& Hsiang-Lin, 2007).

Aremu (2018) opined that the primary goal of auditing is to provide a report that is fact finding without any forms of manipulations in terms of credibility and acceptability. However, the collapse of many big corporations both home and abroad which were not limited to world Com and Enron in the United states as well as Cadbury Nigerian plc and Lever Brothers plc in Nigeria were attrib- 
uted to poor audit quality and breach of trust in connection to a perceived lack of independence of auditor and mandatory auditor rotation (Otusanya \& Lauwo, 2010). However, empirical evidence from the previous studies on the subject matter shows that several factors such as audit fee, audit report lag, mandatory auditor rotation, audit firm reputation and auditor's tenure, were found to be the main determinant of audit quality in different sectors specifically in the banking and manufacturing sector. In the light of this to the best of the researchers knowledge little or no studies of this nature has been carried out with respect to the pharmaceutical firms, it is important and worthy of note that pharmaceutical industry in Africa assume a strategic position especially in Nigeria considering economic potential of the pharmaceutical industry for growth (African Development Bank Group, 2018). The high incidence of diseases in this part of the world and the emergence of Covid-19 has made the pharmaceutical industry to be a vibrant market and one of the fastest growing sectors of the economy with an estimated growth rate of $13 \%$ annually given credence to the outbreak of new pandemics such as Ebola and Covid-19 (Pharmaceutical market sector report, 2017; Ayinde, 2019) In the light of this background, this study intend to investigate the efficacy of audit fee on audit quality of Pharmaceutical firms in Nigeria in an attempts to bridge the identified gap. To guide the thrust of this study, the following null hypotheses were tested:

$\mathrm{H}_{1}$ : Audit fee has no significant effect on the audit quality of Nigerian Pharmaceutical firms.

$\mathrm{H}_{2}$ : Audit report lag does not significantly affect the audit quality of Nigerian Pharmaceutical firms.

$\mathrm{H}_{3}$ : Mandatory auditor rotation has no significant effect on the audit quality of Nigerian pharmaceutical firms.

\section{LITERATURE REVIEW}

\section{Conceptual Review}

Bolanle (2011) posits that audit quality is all about how well information misrepresentation and manipulation are detected and reported through an audit assignment for the purpose credibility and acceptability of an annual reported financial statements. However, the detection aspect audit assignments mainly as to do with the reflection of auditor's competence while reporting is primar- 
ily a reflection of ethics or auditor's integrity in relation to independence. Opeyemi (2017) posits that audit quality comes to play only when an auditors is able to objectively discover and reported misstatements and manipulations in the annual net income reported statement. Similarly, Aremu (2018) opined that a reported net income statement of a company is said to be a reflection of audit quality when the interest of users of financial statement is protected for decision making from diminution of information asymmetry which is made possible through a cosmetic reportage. Ibrahim (2019) stated that audit quality is only attainable when the annual audited financial statement is free from information asymmetry with respect to window dressing.

\section{Audit Fee and Audit Quality}

Simunic (1980) cited by Kolade (2017) views audit fee as a product of unit commission and the quantity of audit assignment demanded by the management of the auditee. In the same vein Ibrahim (2019) opined that audit fee is the charges made by an audit firm for the rendition of audit related services. However, audit service related charges are usually induce by the quantum of audit service rendered by an audit firm. Oludiji (2018) stated that audit fee or compensation is driven by the scope of rendered as well as resources expended and the expected future loss arising from the audit assignment engagements which are not limited to litigation losses and government penalties. Perhaps, one can say that audit fee is a function of cost incurred in performing an audit assignment. Mamud (2017) posits that audit fee is the amount received by an auditor for the purpose of reporting the true and fair state of affairs or position of the client's enterprise in relation to net income statement.

\section{Audit Report Lag and Audit Quality}

Aremu (2018) opined that audit report lag is all about the number of days from fiscal year end to audit report date which has the tendencies of jeopardizing the quality of audited reports by not providing timely information to users of financial information such as investors. Ayinde (2019) posits that delayed in reportage of fiscal year financial activities of an entity usually gives room for information asymmetry thereby eroding intending investors' confidence. Audit report lag induce the reaction of users of audited reports to earnings an- 
nouncement therefore an unnecessary reporting lag are usually a case of poor audit quality.

\section{Mandatory Auditor Rotation and Audit Quality}

Olowookere and Adebiyi (2013) assert that mandatory auditor rotation prevents the audit firm from developing a close relationship with the client which makes the audit firm to carry out its work without compromising the ethics standard owing to the fact that they are aware that they have a specific timeframe and this voraciously limit misrepresentation of fact which increase reporting conservatism. In the opinion of Olamide (2018) mandatory auditor rotation have the tendencies of increasing the quality of audit service rendered by an audit firm because the audit firm would attempt to differentiate themselves from other firms by maintaining ethical standard in the course of service rendition, this will equally give room for auditor independence thereby promoting audit reportage quality.

\section{Audit Firm Independence and Audit Quality}

Iyoha (2015) opines that an auditor is said to enjoy independence only when his free from any undue influence in the course of performing audit assignment. Auditor's independence is said to be attain only when integrity is maintain and the audit assignment is driven by objectivity. Iyoha (2015) cited by Bolajoko (2015) views auditor's integrity as the aspect of his character rooted in his conviction which prevent him from taking a subjective position in connection with audit service rendition regarding the upholding of professionalism by not taking undue advantage of his position to make riches.

\section{Auditors Tenure and Audit Quality}

Sheu (2018) posits that the length of an auditor usually induce the credibility of an audited financial statement given credence to the fact that the closeness to client management can be seen as a condition that affects audit quality. Are$\mathrm{mu}$ (2018) stated that auditor may not exhibit sufficient professional conduct while performing audit assignment once that is a long-term closeness between the management and the auditor which will adversely induce the credibility 
of the audit assignment outcome. Contrarily, Ibrahim (2019) opined that longterm auditor-client relationship usually resulted to more audit reporting success than when auditors had served these clients for shorter tenures. This suggests that the shorter the lower the audit quality.

\section{Theoretical Underpinning}

This study hinges on the reviewed of both the agency and the theory of inspired confidence, evidence from the review of the agency theory and the theory of inspired. The former links shareholders and the management who are the providers of financial statements to be audited by Audit firms and the latter anchored managers and audit firms that play a prominent role in ensuring quality of financial reporting. In the light of the foregoing the researcher deems it fit to draw a line of appropriateness for the adoption of agency theory for this study because it has a link with the study specific objectives.

\section{Empirical Review}

Yuniarti (2011) empirically investigate the factors that affect audit quality of 24 listed Bandung firms in 2009. A secondary data was extracted from annual audited reports from the population under study. Based on the finding from the study it was reveal that higher audit fees increase and improve audit quality due to auditor's effort. i.e audit fees has a positive significant relationship with audit quality of the population under study. It was recommended that accounting firms should enhance amount of audit fees considering it effect on the overall credibility of audit quality.

Oladipupo (2011) investigated the impact of audit lag on financial report quality in Nigeria. He selected Forty companies to serve a fair representation of the population under study. He employed Both univariate and multivariate to performed his analyses on the collected data in a bid to query his hypotheses statement. The study observed that; audit delay ranged from 16 to 284 days has an impending effect on the quality of financial reports of the population under study. It was recommended that audit report delay should be totally frown at to enable users of audited reports to have access to audited reports timely to limit the problem of asymmetric information. 
Llaboya and Ohiokha (2014) examines the impact of audit firms' characteristics on audit quality. The data used for the study was extracted from the audited statement of the population under study. A GLS regression model was employed to establish the nature of relationship that exists between the dependent and independent variables. Based on the study outcome it was revealed that a negative relationship exists between auditors's independence, audit firm size, audit tenure all as proxies for the independent variables and audit quality being the dependent variable. It was recommended among others that to ensure audit quality auditors must enjoy independence to ensure professionalism.

Onaolapo, Ajulo and Onifade (2017) evaluates the effect of audit fees on audit quality listed cement companies on the floor of the Nigerian Stock Exchange. specifically, the study examines the relationship between audit fee, audit tenure, client size, leverage ratio and audit quality. OLS Model was used to analyze the relationship between the independent variables and the dependent variable using the secondary data derived from the audited reports of the selected companies for a six year period 2010-2015. The study shows that audit fee, audit tenure, client size and leverage ratio are jointly significant in explaining audit quality given credence to the model coefficient of $\left(R^{2}\right)$ which stood at 0.6006 this implies that the independent variables can explain about $60 \%$ changes in audit quality is about $60 \%$. It was recommended that Government should develop robust policies that will improve audit quality in Nigeria.

Adeniyi (2018) examine the relationship between the tenure of auditor and audit quality in Nigeria. Findings reveal that there is a negative relationship between auditor tenure and audit quality though the variable was not significant. It is therefore in cognizance of the foregoing that study seek to examine the efficacy of audit fee on audit quality of the selected pharmaceutical firms in an attempt to bridge the identified gap.

\section{The Research Methodology and the Course of the Research Process}

\section{Research Strategy}

The study employed descriptive research design. Analysis was based on available annual secondary data collected over the study period (2009-2019). The descriptive research design enhanced detailed analysis with a view of drawing inferences in logical sequences. However, the sample size of this study was re- 
stricted to the topmost ten Pharmaceutical companies listed in Nigeria Stock exchange as at December 2019 and they include; Afrik Pharmaceuticals Plc, Evans Medical Plc, Fidson Healthcare Plc, Glaxo Smithkline Consumer Nigeria Plc, May \& Baker Nigeria Plc, Neimeth International Pharmac euticals Plc, NigeriaGerman Chemicals plc, Pharma- Deko Plc to serve as fair representation of the population under studied.

\section{Model Specification}

This study was modelled according to the accrual quality model of Fuad (2012) which was modified by Bolajoko (2015) and Onaolapo, Ajulo and Onifade (2017) but specifically, this study adapted the model of Onaolapo, Ajulo and Onifade (2017) which studied the effect of audit Fees on audit quality a selected Cement Manufacturing Companies in Nigeria as a sample size. Onaolapo, Ajulo and Onifade (2017) specified their model as: AUDQUAL $=\alpha+\beta_{1}$ AUDFEE $+\beta_{2}$ AUDTEN $+\beta_{3}$ CLTSIZE $+\beta_{4}$ LEV $+\mu$; Where: AUDQUAL $=$ Audit quality, AUDFEE $=$ Audit fee, AUDTEN = Auditor's tenure, CLTSIZE $=$ Client size and LEV $=$ Leverage In a bid to test for the significance of the formulated hypotheses, the below econometric models was formulated to suit the specific objectives of this study.

$$
A U Q_{i, t}=A F_{i, t}+A R L_{i, t}+M A R_{i, t}+A F I_{i, t}+A T_{i, t}
$$

Where:

$\mathrm{AUQ}_{\mathrm{i}, \mathrm{t}}=$ audit quality of the selected firms in year $\mathrm{t}$

$\mathrm{AF}_{\mathrm{i}, \mathrm{t}}=$ audit fee of the selected firms

$\mathrm{ARL}_{\text {it }}=$ audit report lag in year $\mathrm{t}$

$\mathrm{MAR}_{\mathrm{it}}=$ mandatory auditor Rotation in year $\mathrm{t}$

$\mathrm{AFI}_{\mathrm{it}}=$ audit firm independence in year $\mathrm{t}$

$\mathrm{AT}_{\text {it }}=$ auditor Tenure in year $\mathrm{t}$

The model to be estimated becomes:

$$
\begin{aligned}
& \mathrm{AUQ}_{\mathrm{i}, \mathrm{t}}=\beta_{0}+\beta_{1} \mathrm{AUDF}_{\mathrm{i}, \mathrm{t}}+\beta_{2} \mathrm{ARL}_{\mathrm{i}, \mathrm{t}}+\beta_{3} \mathrm{MAR}_{\mathrm{i}, \mathrm{t}}+\beta_{4} \mathrm{AFI}_{\mathrm{i}, \mathrm{t}}+\beta_{5} \mathrm{AT}_{\mathrm{i}, \mathrm{t}}+\mu_{\mathrm{i}, \mathrm{t}} \\
& \beta_{0}, \beta_{1}, \beta_{2}, \beta_{3}, \beta_{4} \text { and } \beta_{5} \text { parameters of estimation } \\
& u_{i t}=\text { the error term } \\
& \mathrm{i}=\text { cross-sectional variable } \\
& \mathrm{t}=\text { time series variable }
\end{aligned}
$$


Panel data estimation technique was used to investigate the subject matter within the period of 2009 - 2019 due largely to the fact that it takes care of heterogeneity which may lead to spurious regression.

\section{Data Presentation, InTERPREtation and Discussion of Findings}

\section{Descriptive Statistics}

The table below presents the descriptive statistics for the dependent proxy as Audit quality and explanatory variables of selected pharmaceutical firms. The table present information on the character that the collected data exhibit.

Table 1. Descriptive Statistics of the Variables

\begin{tabular}{|l|c|c|c|c|c|}
\hline \multicolumn{1}{|c|}{ Variables } & Obs & Mean & Std. Dev. & Min & Max \\
\hline \hline AQT & 80 & .0804 & .1087 & 0.0251 & .6502 \\
\hline AF & 80 & .0907 & .2064 & 0.0423 & .8705 \\
\hline ARL & 80 & .0431 & .0342 & 0.000 & 1.000 \\
\hline MAR & 80 & .2105 & .1301 & 0.000 & 1.000 \\
\hline AFI & 80 & .0675 & .0274 & 0.000 & 1.000 \\
\hline AT & 80 & .3342 & .3634 & 0.000 & 1.000 \\
\hline \hline
\end{tabular}

S o u r c e : researcher's computation (2020).

\section{Pairwise correlation}

The table below presents the results of correlations among the variables. The logic behind the assumption of no multicollinearity is that correlation coefficient between two variables is must not be greater than 0.70 (Gujarati, 2015) .

Thus, evidence from table reveal tha all adopted variables were not significantly correlated with each other base on the range value of variables correlation of the lowest and the highest correlation value suggesting the absence of multi-colinearity among the adopted variables for this model. 
Table 2. Pairwise correlation

\begin{tabular}{|l|c|c|c|c|c|c|}
\hline \hline \multicolumn{1}{|c|}{ var PbvVariable } & AQT & AF & ARL & MAR & AFI & AT \\
\hline \hline AQT & 1.0000 & & & & & \\
\hline AF & 0.4216 & 1.0000 & & & & \\
\hline ARL & -0.3402 & 0.1256 & 1.0000 & & & \\
\hline MAR & -0.5312 & 0.4217 & -0.2401 & 1.0000 & & \\
\hline AFI & 0.3201 & 0.2613 & 0.4746 & 0.3481 & 0.4323 & \\
\hline AT & 0.4210 & 0.2034 & 0.4215 & 0.2004 & 0.3014 & 1.0000 \\
\hline \hline
\end{tabular}

S o u r c e : researcher's computation (2020).

\section{REgRESSION ANALYSIS}

An hausman test was firstly conducted to decide on the best estimates between random and fixed effect. The result of the hausman test reveals chi2 value of 7.55 with 0.1864 probability which is $>$ the 0.0500 significant margin. This implies that the random effect was the best model to be estimated.

Table 2. Hausman specification test

\begin{tabular}{|ccccc|}
\hline \multicolumn{7}{c}{ Coefficients } & (b) & (B) & (b-B) & sqrt (diag (V_b-V_B)) \\
\hline \multicolumn{7}{c}{ fixed } & random & difference & S.E. \\
\hline AF & .0152 & .1040 & .0177 & .0105 \\
\hline ARL & -.1316 & -.1350 & -.0641 & .3103 \\
\hline MAR & -.1243 & -.0514 & -.0042 & .0027 \\
\hline AFI & .0212 & .0062 & .0077 & .0310 \\
\hline AT & .0511 & .0812 & .0140 & .0121 \\
\hline Test: Ho: difference in coefficients not systematic \\
\hline \multicolumn{7}{c}{ Prob>chi2 = 0.1864} \\
\hline
\end{tabular}

S o u r c e : researcher's computation (2020).

The below result shows that the coefficient of R-squared has a value of 0.7241 implies that independent variables surrogate were able to explain about $0.72 \%$ of change in audit quality this posits that the explanatory variables constitute $72 \%$ of the elements that predict the dependent variable. Thus, the stochastic 
element in the model constitute about $28 \%$, in view of this one could draw a line of conclusion that the model exhibit a strong goodness of fit.

The F-statistics was Statistically significant at $1 \%$ with a probability value of 0.0000 which implies that all independent variables were jointly significant in explaining the dependent variable. The coefficients of the constant (C) has a value of 0.0528 . This suggests that if all the explanatory variables are held constant, the explained variable which will surge by 0.0528 units. This implies that regardless of change in the explanatory variables the selected pharmaceutical companies audit quality will respond according.

A positive coefficient of 0.2040 was reported for audit fee and it was statistically significant at $1 \%$ level. This posits that in a situation where other predictor variables are held constant, by implication a unit change in Audit fee will account for 0.2040 units increase in the audit quality of the selected pharmaceutical firms. This was in agreement with the work of Kolapo (2018) who equally reported a positive significant nature of relationship between audit compensation and audit service quality.

A consideration of the strength of relationships, using the t-statistic shows that audit report lag whose z-statistics is -4.02 relates significantly with the selected firms audit quality given its 0.000 probability which is above the 0.0500 significant margins. This implies that a negative nature of relationship exit between audit report lag and audit quality, this suggest that delay disclosure of audited statement usually induced the quality of financial reportage. Therefore, the longer the audit report lag the lower the quality of the audited statement.

A negative coefficient of- 4.00 was also reported on mandatory auditor rotation and it was significant at $1 \%$. This, posits that the longer mandatory auditor rotation give room for a cordial client-agent relationship which is likely to put ethical standard into jeopardy. A consideration of strength of the negative coefficient of- 4.00 posit that a shorter mandatory auditor rotation is essential to mitigate audited financial statement misrepresentation as this will go a long way in improving audit quality. This result is however in disagreement with the outcome of Ayodeji (2018) who found a positive insignificant relationship between mandatory auditor rotation and financial report quality. However, the other adopted control variables equally has a significance effect on the audit quality of the selected pharmaceutical firms considering the reported coefficient of each of the control variables. Although each of this control variables exhibit different characteristics concerning the specific form of relationship on the audit quality of the selected pharmaceutical firms specifically; Audit firm 
independence reveals a positive coefficient of 0.3233 and it was statistically significant $5 \%$, this suggests that a unit change in the Audit firm independence will account for an increment of 0.3233 units in the audit quality of the selected pharmaceutical firms. This is in agreement with the outcome of Bolanle (2011) who also found a positive relationship between audit firm independence and audit quality.

Auditor's tenure also have a positive coefficient of 0.0897 but not statistically significant at $10 \%$. This suggests that where other regressors are held constant, a unit change in the Auditors tenure will be responsible for an increase unit of 0.0897 in the audit quality of the selected firms.

Table 3. Panel data regression results (Random Effects)

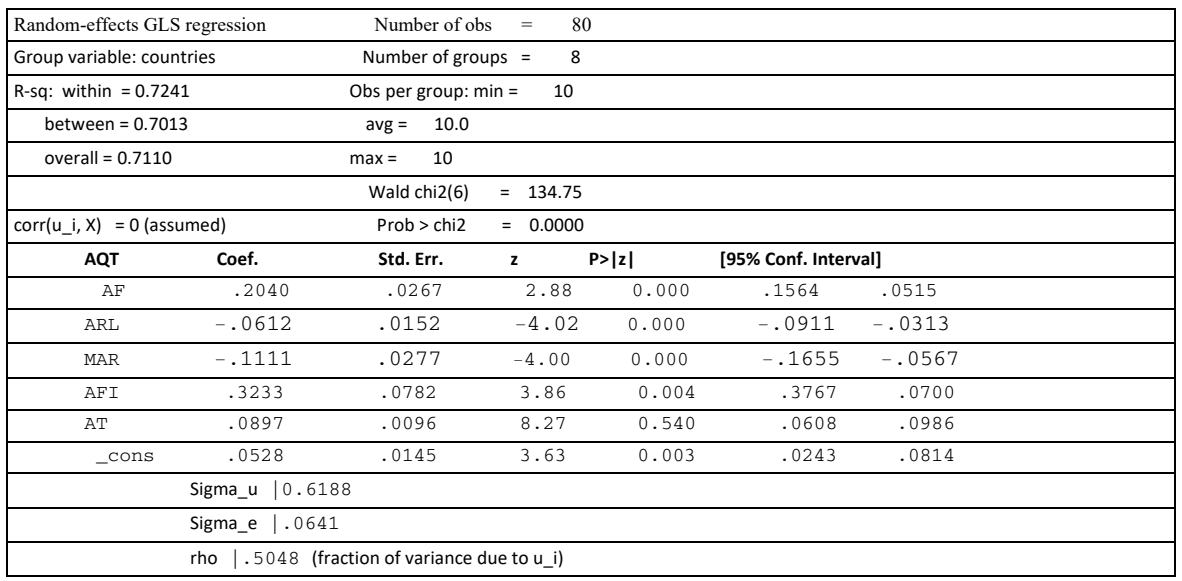

S o u r c e : researcher's computation (2020).

\section{CONCLUSION AND RECOMMENDATIONS}

Based on the empirical findings of this study, it was revealed that audit fee play crucial role on the quality of audited statement of pharmaceutical firms in $\mathrm{Ni}$ geria this is evidenced by the positive coefficient that was reported which signal that the higher the audit fee, the higher the accuracy and reliability of audited statement of account of an organization. The, positive coefficient that was reported on audit fee posits that the selected pharmaceutical firms are really are paying the specified audit rate because of it clear cut effect on the quality of 
audited financial statement considering the reported inferential result which was statistically significance at $1 \%$.

Similarly, the empirical results equally shows that audit report lag equally has a significant influence on audit quality of the selected pharmaceutical firms given cognizance to the inferential statistic results which suggest that delay disclosure of audit account usually erode the confidence of audited statement users. This underscored the need to encourage timely disclosure of audited statement as this will no doubt promote audit quality and conservatism. A negative significant coefficient was also reported for mandatory auditor rotation as a factor that induce audit quality considering the fact that longer mandatory auditor rotation usually poses threat on ethical standard due to long time cordial client -agent relationship.

In line with the outcome of this findings, it was recommended that policy makers and regulators should put in place a framework that will ensure the payment of optimal compensation to audit firm as audit fee, also delay disclosure audited statement (audit report lag) should be discourage as this will improve the audit quality with respect to the users confidence on audited financial statement. Finally, the mandatory auditor rotation legal framework must be reinstituted and respected by all and sundry considering it influence on audit quality evidenced by it reported negative significant coefficient estimated model for the population under study.

\section{REFERENCES}

Adeniyi, D. (2018). Efficacy of the relationship between the tenure of auditor and audit quality in Nigeria. A case study of coglomerate firms. Journal of Management, 4(2), 105-120.

African Development Bank Group (2018). African Nations Financial growth Strategy' Summary Report, Abuja.

Akin, S.A. (2017). Impact of audit quality on firms performance in Nigeria: Evidence from Manufacturing Firms. International Journal of Accounting, Finance and Management, 6(4), 2-37.

Aremu, M.A. (2018) Determinants of audit quality in the banking sector. Research Paper African Economic Research Consortium, 179.

Ayinde, D. (2019). Effect of audit remuneration on financial report quality. Business \& Finance Journal, 1(5), 23-40.

Bolajoko, G. (2015). Influence of corporate governance on audit and non-audit fees. The Australasian Accounting Business \& Finance Journal, 1(4), 40-61. 
Bolanle, M. (2011). Effect of firm characteristics on the quality of financial reports: A case of manufacturing firm listed in the Indonesia Stock Exchange. Faculty of Economy, Gunadarma University.

Gujarati, D. (2015). Basic Econometrices. New York, United State of America: Mc Graw.

Ibrahim, M. (2019). An empirical analysis of audit fees influence on audit quality in Nigerian firms. Journal of Financial Management, 2(5), 58-69.

Iyoha, A. (2015). Audit firm size, audit fee and audit quality: Evidence from Bangladesh. Journal of Applied Business and Economics, 8, 45-64.

Kolade, A. (2017). An empirical analysis of auditor independence and audit fees on audit quality in Nigerian firms. An unpublished Seminar Report submitted to East Ukrainian National University.

Kolapo, N. (2018). Effect of audit compensation on audit service quality in Nigeria. A case of consumer goods. An unpublished PhD. Seminar Report submitted to Kwara State University, Malete.

Llaboya, S.C., \& Ohiokha, N.S. (2014). The Impact of Audit Quality on Firm Performance: Evidence from Malaysia Journal of Financial Economics, 13, 187-221.

Mamud, B. (2017). Impact of Audit Independence on Financial Reporting. Journal of Financial Research, 3(1), 208-220.

Oladipupo, F. (2011). Impact of audit lag on financial report quality in Nigeria. A case study of selected listed firms. Journal of Management Accounting, 4, 80-92.

Olamide, L. (2018). Effect of mandatory auditor rotation on financial report quality. Evidence from selected Nigerian deposit money Banks. Journal of Accounting, 5(3) $59-72$.

Olowookere, A., \& Adebiyi, A. (2013). Effect of mandatory auditor rotation on audit quality. Evidence from Cement Manufacturing Companies in Nigeria. Journal of Financial Accounting, 5, 100-119.

Oludiji, A. (2018). Effect of Nonaudit Services on Audit Quality. Singaporean Journal of Business Economics, and Management Studies, 2(11).

Onaolapo, A.R., Ajulo, O.B., \& Onifade, H.O. (2017). Impact of Audit Fees on Audit Quality: Evidence from Cement Manufacturing Companies in Nigeria. Journal of Financial Economics, 5(1), 157-185.

Opeyemi, R. (2017). Effect of firm characteristics on the quality of financial reports. An unpublished M.Sc. Seminar Report submitted to University of Ilorin.

Otusanya, I.M., \& Lauwo, J.P. (2010). Effect of audit quality on Company Performance: Evidence from Nigeria goods sector. Journal of Economics and Management, 18(2), 580786.

Pharmaceutical market sector report (2017). Vision 2020: Innovation Management and pharmaceutical firms Development Sustainability.

Shen, T., \& Hsiang-Lin, E.M. (2007). The Impact of audit quality on Firms Performance: Evidence from Saudi Arabia. Journal of Applied Finance and Banking, 5(2), 363-463.

Sheu, H. (2018). Influence of auditors tenure on audit quality of Iranian listed firms. Journals of management, 2(3), 97-115.

Yuniarti, P. D. (2011). Evaluating Value Based Financial Performance Measures, Journal of Finance and Accounting, 5, 56-63. 